\title{
Prepositions with CP and their implications for extended projections*
}

\author{
Peter Svenonius \\ CASTL, University of Tromsø- \\ The Arctic University of Norway
}

September 21, 2019

\begin{abstract}
In some limited cases, English allows a particular preposition to combine with a certain kind of subordinate clause, as exemplified by in that in "I take the proposal seriously, in that I loathe it". In contrast, Norwegian systematically allows prepositions to combine with subordinate clauses (as in Det resulterte $i$ at vi vant, literally "It resulted in that we won"). I argue that the English case should be handled as the subcategorization for a certain complement class by a particular lexical entry, while the Norwegian case indicates that the extended projection of clauses can continue up to the preposition. This highlights an important difference between lexical selection and extended projection, revealing a hitherto underappreciated source of parametric variation, and sheds light on several properties of extended projections as well as of prepositions. Specifically, the extended projections of N and V may "converge" at $\mathrm{P}$, challenging the notion of extended projection as being confined to a single lexical category.
\end{abstract}

Keywords: Preposition, extended projection, selection, functional hierarchy, Norwegian

\section{Introduction}

\subsection{Three kinds of phrases}

Most if not all phrases in natural languages are headed, which is to say they have a structure schematically like the following, where $\mathrm{H}$ stands for head (and its projection) and $\mathrm{N}$ stands for nonhead.

\footnotetext{
*To appear in 2021 in Linguistic Variation, (C)John Benjamins https:doi.org/lv.00032.sve
} 
$(1)$

$$
\widehat{\mathrm{H} \mathrm{N}}_{\mathrm{N}}^{\mathrm{H}}
$$

Such phrases can be subclassified into those in which $\mathrm{N}$ is an adjunct to $\mathrm{H}$ and those in which $\mathrm{N}$ is not an adjunct. Among those cases in which $\mathrm{N}$ is not an adjunct, a further distinction can be drawn: those in which $\mathrm{H}$ is an extended projection of $\mathrm{N}$, in the sense of Grimshaw (1991), and those in which $\mathrm{N}$ is a selected or subcategorized argument of $\mathrm{H}$. For the sake of brevity, I will refer to these cases using the abbreviations EP for extended projection and SA for selected (or subcategorized) argument.

Often, the distinction between EP and SA is assumed to correlate perfectly with a presumed distinction between functional and lexical $\mathrm{H}$ : if $\mathrm{H}$ is functional, then (1) is an example of $\mathrm{EP}$, and if $\mathrm{H}$ is lexical, then (1) is a case of SA.

However, this heuristic does not necessarily resolve the question of the nature of a structure like (2), illustrated by the nonsynonymous English (3) and Norwegian (4), in each of which a prepositional head combines with a clausal CP complement (I will presume uncontroversially that the structures in question do not involve adjunction; for one thing, the $\mathrm{CP}$ is not optional).

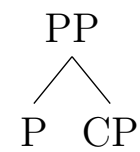

(3) Everyone is agreed, in that nobody objects.

(4) Alle er enige $i$ at ingen protesterer. all er agreed.PL in that nobody objects

'Everyone agrees that nobody objects'

Prepositions have been analyzed as essentially functional by, e.g., Fillmore (1968), Emonds (1985) and Grimshaw (1991), or as essentially lexical, by, e.g., Jackendoff $(1973,1977)$, and Baker (1988), and it has been argued that there are both lexical and functional prepositions (e.g., Rauh 1993) or that prepositions are decomposed into extended projections with a lexical base dominated by functional structure (e.g., van Riemsdijk 1990, Koopman 2000, and den Dikken 2010). So the question remains whether structures like those in (3) and (4) are cases of EP or SA.

In this paper I argue that English (3) manifests a case of SA, but that Norwegian (4) illustrates EP, and this difference reveals a parametric difference between the two languages, showing among other things that there is parametric variation in the structure of extended projections. The argument is primarily made on the basis of systematicity; in English, prepositions combine with declarative CP only sporadically, subject to lexical idiosyncracy, consistent with some P selecting CP and other $\mathrm{P}$ not doing so; but in Norwegian, essentially all functional prepositions combine freely with declarative $\mathrm{CP}$, suggesting a categorial generalization. 
The suggestion that $\mathrm{P}$ can dominate $\mathrm{CP}$ in an extended projection flies in the face of Grimshaw's $(1991 ; 2005)$ analysis in which $\mathrm{P}$ is at the top of the extended projection of N. It recalls Emonds' (1985) unification of P and C and van Riemsdijk's (1998) analysis of $\mathrm{P}$ as nondistinct from both $\mathrm{N}$ and $\mathrm{V}$ (allowing $\mathrm{P}$ to appear with either without violating van Riemsdijk's (1990) Categorial Integrity Thesis (CIT) requiring all elements in an extended projection to share a major lexical category). I argue that the Norwegian data fits in with a broader pattern of mixed extended projections in which nominal projections dominate verbal ones, as proposed by Abney (1987), Borsley \& Kornfilt (2000), and Alexiadou (2001), among others, but resisted by both Grimshaw and van Riemsdijk.

\section{Data}

\subsection{English in that}

The English example in (3) illustrates a use of in with a finite that-CP complement, as exemplified further in $(5) .^{1}$

(5) a. Software platforms are a unique business in that instead of a single customer, they require acquiring two or more distinct customer groups

b. Harold is the "object" of George's crime of narcotics distribution (in that George sold the drugs to Harold).

c. We emphasize that this situation was remarkable in that the absence of any one of these four conditions would have prevented its occurrence.

d. The lotion didn't help in that the rash is as bad as before.

These can be analyzed in terms of a lexical entry for in, with a meaning something like 'in the sense that', subcategorizing for a that-CP (C in (6) stands for 'Complement' or alternatively for 'c-selection', invoking Pesetsky's (1982) term for complement subcategorization).

(6) Partial lexical entry for in in, $\mathrm{P}_{[\mathrm{C}: \mathrm{CP}]}$, 'in the sense'

The restriction to a narrow meaning for in is necessary because other uses of in don't support CP.

(7) a. There's no point in your being angry.

b. *There's no point in that you are angry.

It is common for specific senses of words to be coupled with specific subcategorization requirements, for example imagine with a CP can express a guess, while imagine with a DP cannot express a guess.

\footnotetext{
${ }^{1}$ The examples in (5), and the corpus examples of English which follow, are from the Corpus of Contemporary American English (COCA), accessed at https://www.english-corpora.org/coca/. In some cases I have lightly edited the examples for concision.
} 
(8) a. I imagine that you're younger than me = I guess you're younger than me b. I imagine your age $\neq$ I guess your age

\subsection{English P-CP more generally}

It turns out that the unacceptability of $i n+\mathrm{CP}$ in (7) is more characteristic of English than is the acceptability of $i n+\mathrm{CP}$ in (5). The general badness of $\mathrm{P}+\mathrm{CP}$ is illustrated in (9-14) with the most frequent English prepositions of, to, for, with, on, and at, with about thrown in for good measure (in having already been exemplified).

(9) a. I'm not a fan of people smoking around me.

b. *I'm not a fan of that people smoke around me.

(10) a. He was incompetent in addition to his generally dismissive attitude

b. *He was incompetent in addition to that he was generally dismissive ${ }^{2}$

(11) a. I got a medal for winning.

b. *I got a medal for that I won.

(12) a. Let's start with each person suggesting a topic.

b. *Let's start with that each person suggests a topic.

(13) a. I depend on help from a technician.

b. *I depend on that a technician helps me.

(14) a. We were taken aback at your proposal.

b. *We were taken aback at that you proposed to fire the entire board.

(15) a. Think about snails needing a place to hide.

b. *Think about that snails need a place to hide.

Occasional examples are encountered, for example those given below (from COCA).

\footnotetext{
${ }^{2}$ This is unacceptable $(*)$ on a reading where that is a complementizer; this string as written is acceptable on an irrelevant reading with that as a demonstrative pronoun, with intonation breaks before and after in addition to that).
} 
(16) a. ?Everyone is familiar with that it involves needles. [of acupuncture]

b. ?You didn't have any indication of that it might be better that way.

c. ?It was based on that it was getting dangerous.

Such examples are infrequent in corpora and usually sound degraded. I have marked them with question marks, rather than stars, in acknowledgement of the fact that they are attested, but I believe them to have the same status as the starred examples in (7) and (9-15).

\subsection{Norwegian P-CP}

In contrast to English, Norwegian systematically allows declarative CP complements to P.

(17) Man må tenke på at sneglene trenger gjemmesteder one must think on that the.snails need hide.places

'One must consider that snails need hiding places'

To show that the pattern is systematic and robust, examples are presented in (18-25) using the most frequently occurring prepositions in Norwegian (from the NoWaC corpus, ${ }^{3}$ lightly edited): $p a ̊$ 'on', $i$ 'in', til 'to', med 'with', for 'for', av 'of', om 'about', fra 'from', and ved 'by'. In each pair of examples, the first shows a finite clause after the preposition, and the second shows a noun phrase after an equivalent use of the same preposition.

a. Sjølv tviler eg på at eg gidder self doubt I on that I bother

'I myself doubt that I will bother'

b. Sjølv tviler eg på nytten av andre behandlingsformer. self doubt I on the.utility of other treatment.forms

'I myself doubt the usefulness of other forms of treatment'

(19) a. Det er nemlig en grunn til at slike tester ikke er godtatt $i$ it is in.fact a reason to that such tests not is accepted in retten

the.court

'There is in fact a reason that such tests are not accepted in court'

\footnotetext{
${ }^{3} \mathrm{~A}$ web-based corpus of about 700 million words, accessed via the Tekstlab of the University of Oslo, at https://www.hf.uio.no/iln/om/organisasjon/tekstlab/prosjekter/nowac/. The corpus mainly manifests the Bokmål writing style, but a few examples such as those in (18) are in the Nynorsk style.
} 
b. Det er ingen grunn til bekymring

it is no reason to worry ${ }^{4}$

'There is no reason for worry'

(20) a. Nok en gang kan jeg oppsummere med at vanlig kost er best yet one time can I summarize with that ordinary fare is best

'Yet again I can summarize that ordinary (dietary) fare is best'

b. Jeg kan oppsummere med hennes egne ord

I can summarize with her own words

'I can summarize with her own words'

(21) a. Ser at ikke alle blir like glad for at jeg flytter

see that not all become equally happy for that I move

treningsbiten

the.exercise.part

'I see that not everybody is equally happy that I am moving the exercise part (of the blog)'

b. Vi er så glad for denne responsen

we are so happy for this response.DEF

'We are so happy about this response'

(22) a. men ikke alle er like fan av at jeg blogger hele tiden

but not all is equally fan of that I blog whole time

'but not everybody is equally a fan of the fact that I blog all the time'

b. Jeg er ingen fan av røyk

I am no fan of smoke ${ }^{5}$

'I am no fan of smoking' (or 'I am no fan of smoke')

\footnotetext{
4 Though the English gloss is ambiguous, the Norwegian til 'to' is unambiguously a preposition, not an infinitive marker, and bekymring 'worry' unambiguously a noun.

5 The word røyk 'smoke' is unambiguously a noun in Norwegian; it may refer to smoke, or to tobacco, or tobacco smoking.
} 
(23) a. Lyden av flammer fra peisen vitner om at vi the.sound of flames from the.hearth bears.witness about that we har en fin tid $i$ møte

have a nice time in meeting

'The sound of flames from the hearth attests that we have a pleasant time to look forward to'

b. Seieren vitner om sterk moral for en spillergruppe som the.victory bears.witness about strong morale for a player.group as har slitt mye og lenge

has struggled much and long

'The victory attests to the strong morale of a group of players that has struggled greatly for a long time'

(24) a. Anfallene skriver seg ofte fra at den elektriske impulsen $i$ the.attacks write REFL often from that the electrical impulse in hjertet går $i$ ring $i$ arrvevet etter infarktet the.heart goes in ring $i$ the.scar.tissue after the.heart.attack

'The arrhythmias often stem from the electrical impulse in the heart going in a circuit in scar tissue left by the heart attack'

b. Anfallene skriver seg ofte fra arrvevet etter infarktet the.attacks write REFL often from the.scar.tissue after the.heart.attack

'The arrhythmias often stem from the scar tissue left by the heart attack'

(25) a. Forholdet ble forandret ved at kirken mistet mye av den the.situation became changed by that the.church lost much of the politiske makten

political power

'The situation was changed by the church's losing much of its political power'

b. Forholdet ble forandret ved et uhell the.situation became changed by a accident

'The situation was changed by an accident'

In each of the above pairs, a finite $\mathrm{CP}$ with the finite declarative complementizer at appears after a preposition which otherwise has its usual distribution, as the head of a complement or modifier to a lexical head or projection, and the second example of each pair shows that each of these prepositions can take a DP instead of a CP. 


\subsection{Infinitive $C P$ s with $P$}

\subsubsection{Infinitive CPs with $P$ in Norwegian}

Norwegian also systematically allows infinitive clauses as the complements to the very same prepositions. In (26-29) I present a sample of pairs of sentences where a preposition appears with an infinitive clause, again paired with noun phrases where the sense of the preposition is held constant. Here the infinitive marker $\stackrel{a}{a}$ is glossed INF; note that unlike English to it does not have the distribution of a preposition in contemporary Norwegian. The Norwegian preposition most closely corresponding to the English preposition to is til; in (28a) the preposition til 'to' is combined with the infinite marker $\stackrel{\circ}{a}$.

(26) a. Du bør tenke på $\stackrel{\circ}{a}$ bestille varer for $\stackrel{a}{a}$ få de til våren you ought think on INF order goods for INF get them to the.spring

'You ought to think about ordering goods in order to get them in time for spring'

b. Du bør tenke på kostholdet ditt for ditt eget beste you ought think on diet.DEF your for your own best

'You ought to think about your diet for your own good'

(27) a. Jeg er ikke glad $i \stackrel{a}{a}$ fryse

I am not happy in INF freeze

'I don't like being cold'

b. Vi er ikke glad $i$ betong og forurensing

we are not happy in concrete and pollution

'We don't like concrete and pollution'

(28) a. Alle er velkomne til å legge inn sine bilder her all is welcome.PL to INF lay in POSS.REFL pictures here

'Everyone is welcome to put their pictures in here'

b. Alle mellom 3. og \%. klasse er velkomne til Kroken barnekor all between 3rd and 7th grade is welcome.PL to the.corner child.choir

'Everyone between grades three and seven is welcome to Kroken Children's Choir'

(29) a. Har mer enn nok med å holde øynene oppe og fä $i$ meg have more than enough with INF keep the.eyes up and get in me nok mat enough food

'It's enough trouble just to keep my eyes open and get enough food' 
b. de fleste lokalpolitikere har nok med sin egen the most local.politicians have enough with POSS.REFL own kommune og de utfordringer som ligger der municipality and the challenges as lie there

'Most local politicians have enough trouble with their own district and the challenges there'

\subsubsection{Infinitive CPs with $P$ in English}

English allows for with infinitives, as illustrated in (30), but only in a particular sense and with an overt subject (setting aside nonstandard varieties). Infinitives without overt subjects, as in (31), and other senses of for, as indicated in (32), do not allow infinitives.

(30) a. I hope very much for you to succeed.

b. I hope very much for your success.

* I hope very much for to succeed.

(32) a. This is evidence for our success.

b. *This is evidence for us to succeed.

The sense of for illustrated in (30) is standardly analyzed as a complementizer, not a preposition (since Bresnan (1972)). If that is correct, then English systematically disallows both finite and infinitive declarative clauses from appearing as complements of functional prepositions (setting aside the status of words like before and because), while Norwegian allows them.

\subsection{Particles}

English does allow verb-particle complex predicates to take a CP complement (as does Norwegian). When the particle happens to also have a use as a functional preposition, as with on and in, this can lead to the surface sequence P-C, as in (33).

(33) a. Never let on that it was to annoy the neighbors.

b. They chimed in that they would be happy to help.

These particles can easily be distinguished from prepositions by the prosody: particles carry a word accent, while prepositions do not. Norwegian, too, has a clear distinction between particle and preposition prosody, and it is clear that examples like those in (18-25) involve prepositions, not particles. ${ }^{6}$

\footnotetext{
${ }^{6}$ I take it that the internal argument of a particle verb is a specifier, not a complement, following Svenonius $(1996,2003)$. In fact, many internal arguments of verbs are probably better thought of as
} 


\subsection{Interrogative $C P$}

English does allow interrogative CPs after prepositions, as does Norwegian.

(34) a. Your earnings are determined by how many units you sell.

b. They couldn't agree on whether to leave.

c. We've answered the question of why the car wouldn't start.

a. Jeg lurte på om vi burde dra.

I wondered on whether we should leave

'I wondered whether we should leave'

b. Inntektene bestemmes av hvor mye man selger.

the.incomes is.decided by how much one sells

'Income is determined by how much one sells'

At a first pass, there is no difference here between Norwegian and English. It seems as if English makes a categorical difference between interrogative and declarative complements to P, while Norwegian does not. For reasons of space, I reluctantly set aside the interesting facts concerning interrogative clauses under $\mathrm{P}$, which are the same in the two languages, and focus on declarative clauses, where the languages contrast.

\subsection{Norwegian differs syntactically from English}

In Norwegian, the generalization is that a preposition can take a CP complement if the general semantics of the context allows it. For example 'I put it in X' requires X to be a location, which cannot easily be described using a CP. But 'I am interested in X' only requires $\mathrm{X}$ to be something that one can be interested in, which is semantically compatible with description in terms of a proposition, as seen in (36).

(36) Vi er interessert $i$ at det må gå for markedspris we is interested in that it must go for market.price

'We want it to sell for the market price' (somewhat more literally, 'We have an interest in it selling for the market price')

But even a verb which takes a locative complement can allow a CP inside a PP, in Norwegian, if the locative complement is used to characterize an abstract location, as in (37).

specifiers than as complements, as in Hale \& Keyser (2002), Borer (2005), and Ramchand (2008). In that case, the internal arguments of particle verbs are like the internal arguments of simple verbs, and so the distribution of DP and $\mathrm{CP}$ complements in the two cases should be approximately similar, as seems to be the case. In contrast, the internal argument of a preposition is sometimes analyzed as a complement according to Svenonius (2007). However, see $\S 3.9$ for discussion of the possibility that the internal argument of a preposition can be a specifier. 


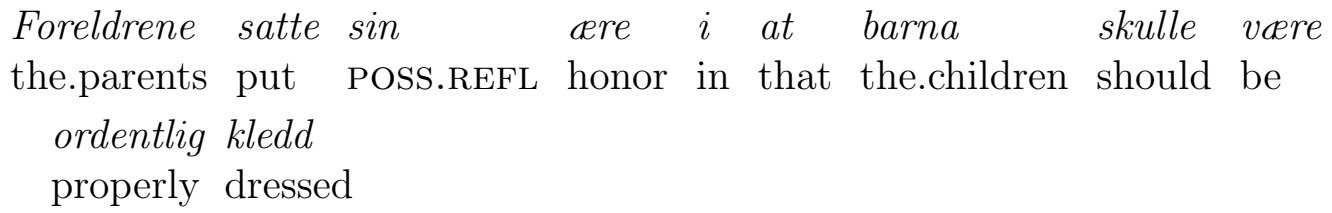

'The parents made it a point of honor that the children be properly dressed' (somewhat more literally, 'The parents put their honor in the children being properly dressed')

Thus the appearance of CP inside an argument or copredicate PP (in Gawron's 1986 terms) in Norwegian appears to be freely allowed by the syntax, and constrained by semantics, while in English it is only possible if the lexical entry of the individual $\mathrm{P}$ specifically allows it. Compare the difference between TP-selecting while and DPselecting during and ambiguously CP or DP-selecting after, as discussed by Emonds (1985) and Haumann (2011).

(38) a. We discussed the matter while $\left\{\right.$ we had lunch $/{ }^{*}$ lunch $\}$.

b. We discussed the matter during $\left\{\right.$ lunch $/{ }^{*}$ we had lunch $\}$.

c. We discussed the matter after $\{$ lunch/we had lunch $\}$.

The differences between while, during, and after must apparently be lexically specified. In contrast, to encode the selection of declarative CP in the lexical specifications of each Norwegian functional preposition would be to miss a generalization. In this article I propose an analysis of this difference between Norwegian and English.

\section{The analysis: Mixed extended projections}

\subsection{S-projections}

Syntactic theory generally distinguishes three kinds of phrasal dependency structures, which can all be taken to be outputs of a combinatory operation Merge (Chomsky 1995): adjuncts, specifiers, and complements. Adjuncts are optional in the sense that the projecting category does not require them, while specifiers are motivated by a thematic or featural requirement. ${ }^{7}$ There may also be a systematic distinction in the interpretation of specifiers and adjuncts, if specifiers are subjects of predication (Stowell 1981) while adjuncts are interpreted under semantic conjunction (a fuller take on this is outlined in Svenonius 2016a, building on Pietroski 2005).

The other type of phrasal structure is one in which a head combines with a complement. ${ }^{8}$ There are two subcases. If the head is lexical (a verb, noun, or adjective),

\footnotetext{
${ }^{7}$ E.g., a possessor is obligatorily introduced by an optional Poss head, which is distinct from the optional adjunction of an adjective. The distinction between specifiers and adjuncts can be questioned, but such considerations are orthogonal to the matter at hand, which concerns complements.

${ }^{8}$ According to Chomsky (2013), the combination of a head with a phrase is the simplest case with respect to the labeling algorithm. Complementation is also potentially special in computational terms. A phrase must be assembled in a workspace prior to being merged with another phrase, but a head need not be affected by any operation in a workspace prior to being merged with its complement.
} 
then the complement is subordinated, just as the nonheads are subordinated in specifier and adjunction structures. However, if the head is functional, then the nonhead is not subordinated in the usual sense. Instead, the functional head forms a kind of extension of its complement, in what Abney (1987) called an s-projection and what Grimshaw (1991) called an extended projection (van Riemsdijk (1990) simply extended the term projection to cover the combination of a functional head with a lexical phrase).

Again, there may be a systematic difference in the interpretations of the two kinds of complements: complements of lexical heads usually have interpretations which are 'complete' in some sense, as objects or properties for example, allowing them to be referred to by proforms or attracted to focus or topic positions, for example. Complements of functional heads are typically not complete in this sense (though verb phrases in some languages can be referred to by proforms and be attracted to focus or topic positions, complicating the dichotomy).

The identification of extended projections is important for many aspects of grammar (Grimshaw 2005). Questions of whether a structure is monoclausal or biclausal revolve in part around whether the parts of the predicate are contained in one or two extended projections. The notion of extended projection allows these same questions to be addressed in nominal and adjectival structures, as well as in structures of mixed category such as the gerund. Many phrases which were analyzed as projections of a lexical head prior to around 1990 are now analyzed as involving collections of functional heads, so that the notion of XP or maximal projection in many cases must be replaced by extended projection. Extended projections also figure in the understanding of words, if words spell out spans (Svenonius 2016b) and spans are normally parts of extended projections.

\subsection{Hierarchy of Domains}

Usually it is assumed that an extended projection has a lexical head N, V, or A at its bottom (or a categoriless root); often this is extended to P (van Riemsdijk 1990) and to Adv, and perhaps a few other categories. ${ }^{9}$

It is furthermore standardly assumed that there is some kind of hierarchy of functional zones, layers, or domains which imposes an organization on the extended projection. Commonly, those domains are associated with C, T, and V (e.g., in Grimshaw 1991; Rizzi 1997), as illustrated in (39), from Ramchand \& Svenonius (2014). Here, three conceptual domains meet at two junctures; the categories at the junctures have properties relevant to two domains each, with the result that there are five layers.

\footnotetext{
${ }^{9}$ However, little seems to hinge on there being a lexical head or root at the bottom of an extended projection; for example if pronouns are D, then it is not clear that they also contain an N. Elbourne (2008) argues for an abstract $\mathrm{N}$ in a class of pronouns, but the matter is unsettled. See also Ramchand \& Svenonius (2002); Ramchand (2008) for examples of verbal structures in which there are extended projections without a sharp distinction between lexical and functional heads.
} 
(39) Ramchand \& Svenonius (2014):

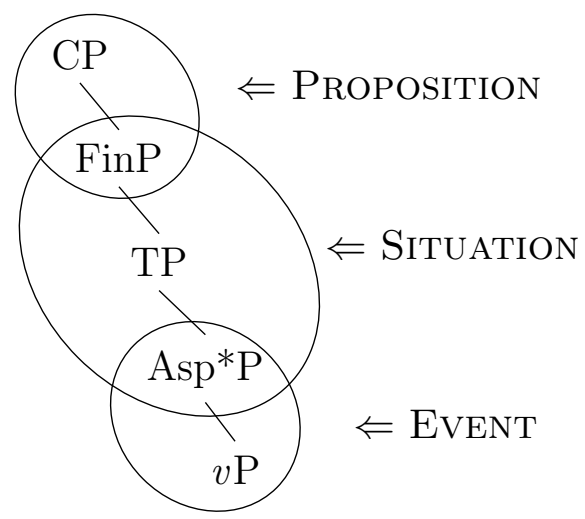

Usually, following Abney (1987), the noun phrase is taken to be organized in the same way. Wiltschko (2014) proposes a hierarchy of four functional domains which impose a structure on both the verbal and the nominal extended projections, as illustrated in (40). Such diagrams are also common in the functionalist literature. ${ }^{10}$

(40) Wiltschko's (2014) functional hierarchy

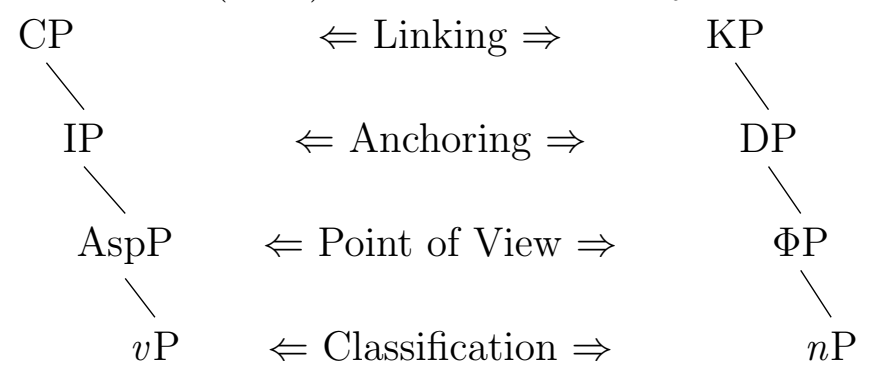

I will refer to hierarchically organized domains like those illustrated in (39-40) as Hierarchies of Domains or HoDs. Van Riemsdijk (1998) tentatively proposed a different kind of hierarchy, one of lexicality, such that lexical categories are the lowest, functional categories are the highest, and semi-lexical or semi-functional categories are in between.

Grimshaw (1991) suggested that categories could be identified with a sequence F0, F1, F2 such that lexical categories are F-level zero and functional categories have successively higher F-numbers. HoP in (41) stands for Hierarchy of Projections.

\begin{tabular}{lcc} 
& verbal HoP & nominal HoP \\
\hline F2: & $\mathrm{C}$ & $\mathrm{P}$ \\
F1: & $\mathrm{T}$ & $\mathrm{D}$ \\
F0: & $\mathrm{V}$ & $\mathrm{N}$
\end{tabular}

In Grimshaw (2005) this was revised to accommodate much larger, cartographic inventories of functional categories such as that of Cinque (1999). There, for example, alethic modal necessity as expressed by necessarily might be F25, higher than alethic

\footnotetext{
${ }^{10}$ For example Rijkhoff (2002), for whom the lowest domain is 'quality', the next one up is 'quantity', including number and aspect, and the highest one is 'location', including determiners and tense.
} 
modal possibility (possibly) at F24. Conceptually, I believe this to be different from the notion of an HoD as illustrated in, for example (39) or (40). An HoD consisting of three to five domains can plausibly be conceptually motivated, as in the proposals of Ramchand \& Svenonius (2014) and Wiltschko (2014), but such motivations do not scale up tenfold. For example, Ramchand and Svenonius' proposal is based on notions like situation and event, which are broad and flexible enough that they are compatible with a wide range of research results. But if a notion like situation were to be broken down into ten component parts, there would be no consensus on how those parts fit together; the results ordering alethic modal necessity over alethic modal possibility are not as broadly supported as those ordering situations (with temporal operators) over events (with thematic role assigners). Cinque (1999) has inspired twenty years of productive research, and there are few direct empirical challenges, but none of that research has brought us close to a conceptual justification for a fine-grained HoD (or so argue Ramchand \& Svenonius 2014).

On the other hand, individual languages regularly show fine-grained hierarchies of ten or more categories, for example in English where $\mathrm{T}$ and modals dominate negation, which dominates the perfect, which dominates the progressive, which dominates the passive, which (arguably) dominates the introducer of the external argument, which dominates the verb; combined with Force over Finiteness in the $\mathrm{C}$ domain (see Baltin 1989 for arguments that Force and Finiteness must reside in distinct heads in the English $\mathrm{C}$ domain) and possibly also positions for such formatives as the be going to future, and the infinitive marker with modals like ought or have to, there are probably more than ten positions in the English clause. Languages like Turkish and Navajo are even richer. So each language has a Hierarchy of Projections, HoP, which can be a partial order, for example in English the have to modal can dominate or be dominated by the perfect, as illustrated in (42).

(42) a. The dishes have to have been rinsed before they are put in the dishwasher (root reading of have to over perfect)

b. The dishes have always had to be rinsed before being put in the dishwasher (perfect over root reading of have to)

I will assume for the time being that there is a universal HoD of about three to five domains, and that each language-specific HoP conforms to it. Below I will revisit the nature of the universal $\mathrm{HoD}$, but for now I will assume that it is consistent with something like (40) and (41). Note that there is significant overlap between K (Case, at the top of Wiltschko's nominal hierarchy) and functional P (at the top of Grimshaw's nominal hierarchy), and $\mathrm{T}$ is a special case of I, so the two hierarchies are fully compatible.

\subsection{Edge Functions}

I will be arguing that languages can differ in the extended projections that they allow (specifically, Norwegian but not English allows declarative C to project to functional $\mathrm{P}$, as in (4) and subsequent examples), so I need a way to represent the set of possible extended projections in a given language. 
Abney (1987) called the selection of a complement category by a functional head $\mathrm{f}$ selection, comparing it to subcategorization by a lexical head. In that case, we could imagine a lexical entry $\mathrm{T}_{[\mathrm{F}: \mathrm{Asp}]}$, for a $\mathrm{T}$ head selecting a complement of category Asp, where F stands for f-select. Grimshaw (2005), on the other hand, argued that extended projection should be thought of in terms of projection upward of the lower head. Adger (2013) implemented this intuition in terms of self-merge: a head merges with itself, and the resulting structure is labeled by a labeling function which introduces the higher category. For example, Asp merges with itself, creating \{Asp, Asp\}, which then requires a label to distinguish it from Asp. The labeling function provides $\mathrm{T}$ as the label for the new object, drawing on an independently stipulated universal hierarchy in which $\mathrm{T}$ dominates Asp.

For Adger, the labeling function for this case is represented as an ordered pair $\langle$ Asp, T $\rangle$. A set of such pairs, like that in (43), defines an HoP, which in turn defines a set of extended projections (Adger refers to such a set as $\mathrm{EP}_{\mathrm{V}}$, the extended projection of $\mathrm{V}$ ).

(43) A Hierarchy of Projections (HoP) represented as a set of pairs (Edge Functions, EFs)

$\begin{aligned}\{ & \langle\mathrm{V}, \mathrm{v}\rangle, \\ & \langle\mathrm{v}, \text { Voice }\rangle, \\ & \langle\text { Voice }, \text { Asp }\rangle, \\ & \langle\text { Asp }, \mathrm{T}\rangle, \\ & \langle\mathrm{T}, \mathrm{C}\rangle\end{aligned}$

This set is equivalent to a directed graph in which the categories are vertices and each pair defines an edge; to link to the notion of edge features which motivate Merge in Chomsky (2007, 2008), I will call the pairs Edge Functions (EFs). ${ }^{11}$ Adger's (2013) general term for any pair $\langle\mathrm{X}, \mathrm{Y}\rangle$ in which $\mathrm{Y}$ dominates $\mathrm{X}$ is label transition function, or LTF. This includes not only pairs like $\langle$ Asp, T $\rangle$ but also $\langle\mathrm{D}, v\rangle$, since $v$ can take a DP specifier. My term EF picks out the subset of LTFs which define extended projections, hence $\langle$ Asp, $\mathrm{T}\rangle$ but presumably not $\langle\mathrm{D}, v\rangle$, since it does not respect $\mathrm{HoD}$, given that $\mathrm{D}$ is higher than $v$ (and whether an LTF like $\langle\mathrm{D}, \mathrm{T}\rangle$ can be an $\mathrm{EF}$ in a given language is an open question). Note that the formulation is deliberately neutral as to whether EFs are motivated by a property of the higher head, as imagined by Abney, a property of the lower head, as suggested by Grimshaw, or are independent of the listed properties of the heads themselves, as suggested by Adger. I will return to this matter below.

I will call the set of EFs for a given language an EPG, for Extended Projection Graph. The EPG of a language $\mathrm{L}, \mathrm{EPG}_{\mathrm{L}}$, contains all and only the EFs in which the first category projects the second (or, equivalently, in which the second takes the first as complement) in an extended projection. $\mathrm{EPG}_{\mathrm{L}}$ defines $\mathrm{HoP}_{\mathrm{L}}$. I will assume that each EPG respects an HoD such as that in (39) or (40).

\footnotetext{
${ }^{11}$ Chomsky $(2008,139)$ observes that a lexical item (LI) "has a feature that permits it to be merged. Call this the edge feature (EF) of the LI." See Boeckx (2010) for discussion of this and other senses of the term "edge".
} 


\subsection{HoPs as directed graphs}

The EPG defines a directed graph in which the vertices are categories. The (partial) EPG in (43) defines the graph in (44), which is clearly a notational variant of the usual way of representing an HoP or maximal extended projection.

$$
\mathrm{V} \longrightarrow v \longrightarrow \text { Voice } \rightarrow \text { Asp } \longrightarrow \mathrm{T} \longrightarrow \mathrm{C}
$$

It is a conclusion of many analyses that some functional heads may be missing from some extended projections. For example, if unaccusatives lack Voice but can have the same Asp head as other verbs, then the EPG must also contain the EF $\langle v$, Asp $\rangle$ as well as $\langle v$,Voice $\rangle$ and $\langle$ Voice,Asp $\rangle$. The addition of the EF $\langle v$, Asp $\rangle$ to (43) defines the directed graph in (45). ${ }^{12}$

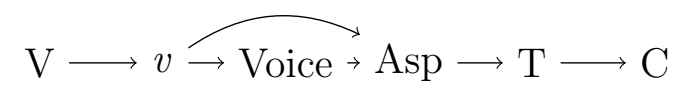

The EF $\langle v$,Asp $\rangle$ thus distinguishes a grammar in which Voice is optional from one in which Voice is obligatory. If grammars can vary on this point, then it must be possible to learn that a grammar has $\langle v$,Asp $\rangle$, i.e., learners must be able to posit EFs on the basis of attempts to parse input structures. An input structure which is interpreted as involving Asp immediately dominating $v$, without an intervening Voice, could not be parsed correctly by a learner whose EPG lacked the EF $\langle v, \mathrm{Asp}\rangle$. The failure of the parse could be the impetus to posit the EF, updating the grammar.

If Asp is also optional in $\mathrm{L}$, then there are $\mathrm{EFs}\langle v, \mathrm{~T}\rangle$ and $\langle$ Voice, $\mathrm{T}\rangle$ in $\mathrm{EPG}_{\mathrm{L}}$, as indicated in (46).

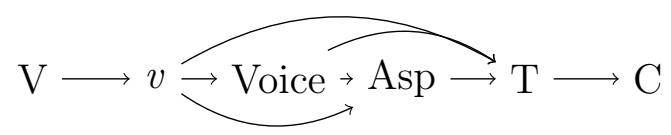

EPG will also include EFs corresponding to the HoP for noun phrases, as in (47). Here I represent $n$ and Num as optional.

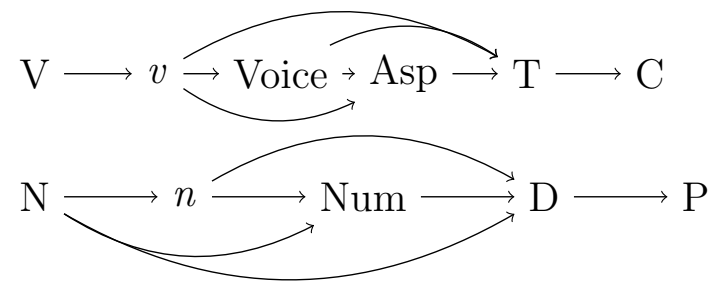

Technically, the picture in (47) is a graph, despite not being connected.

\footnotetext{
${ }^{12}$ This is similar to the notation of marking a category in an extended projection as optional with parentheses, but is descriptively more powerful.
} 


\subsection{Mixed extended projections}

Assuming, as I have so far, that each functional head properly belongs to one lexical category or another, a mixed extended projection is one which includes heads from two different lexical categories (recall from $\S 3.3$ that the EPG of a language defines the set of extended projections possible in that language). Abney's (1987) analysis of the English gerund as involving a D with a VP complement, a mixed projection, was part of the original motivation for s-projections.

$\mathrm{D}$ at the top results in the distribution of a DP and genitive case for the subject, but there is a full verb phrase at the bottom, including heads responsible for accusative case and adverbial modification. The presence of functional verbal structure is furthermore indicated by the possibility of aspectual morphology. In fact English gerunds may include nonfinite T, on an analysis like that of Stowell (1996). However, I represent them here with Asp since there are nominalizations in other languages which appear to be even 'higher' than the gerund (i.e., the crossover from verbal to nominal structure is higher in the HoD and/or HoP) so are clearer cases of including $\mathrm{T}$.

(48) a. [DP Mary's [AspP always having previously denied the facts]]

b. [DP John's [AspP having been singing that song so loudly for so long]]

Grimshaw (2005) and van Riemsdijk (1998) both took categorial integrity to be central to the notion of extended projection, and rejected the analysis of mixed extended projections suggested by (48). However, Grimshaw was by her own admission unable to account for the properties of the gerund that Abney treated. Van Riemsdijk (1998) defined $\mathrm{P}$ as an intermediate category that could allow mixed projections, by being nondistinct both from $\mathrm{V}$ and from $\mathrm{N}$, and suggested that gerunds might contain a similarly intermediate category, but did not work out the details.

Subsequent work would seem to strengthen the plausibility of Abney's treatment. Plausible cases of mixed extended projections have been identified in many languages, including Turkish, Greek, Spanish, Basque, Quechua, and others (e.g., Borsley \& Kornfilt (2000), Alexiadou (2001), Alexiadou (2011), Alexiadou et al. (2011), Kornfilt \& Whitman (2011), and references there). Typically, they involve a nominal projection over a verbal one, respecting HoD. ${ }^{13}$

For example, Borsley \& Kornfilt (2000) and Alexiadou et al. (2011) discuss a construction in Spanish in which a definite article appears with an infinitive clause which includes the possibility of arguments with nominative as well as accusative case, suggesting a TP structure (example (49) is from Borsley \& Kornfilt (2000), and (50) is from Alexiadou et al. (2011)). ${ }^{14}$

\footnotetext{
${ }^{13}$ Some constructions discussed in the literature involve a determiner before a complementizer, which appears not to respect HoD as usually described. However, see Sheehan \& Hinzen (2011) for a discussion of parallels between functions of $\mathrm{D}$ and $\mathrm{C}$ which suggest that some $\mathrm{D}$ and $\mathrm{C}$ may be in the same domain. I will return briefly to a similar case in Norwegian, which I will argue involves adjunction of $\mathrm{CP}$ to a nominal projection and not a mixed extended projection.

${ }^{14} \mathrm{~A}$ challenge is to explain why adjectives are possible with such examples, just in case they precede the lexical head, a possibility pointed out to me by Antonio Fábregas, in a personal communication. Possibly, the modifier (e.g., constante 'constant') appears as an adjective rather than an adverb because of the proximity of $\mathrm{D}$, despite apparently being adjoined to a verbal projection.
} 
No puedo aceptar el haber rechazado tu esa propuesta. NEG can accept the have.INF rejected you.NOM this proposal

'I cannot accept that you rejected the proposal'

(50) el cantar yo la Traviata

the sing.INF I.NOM the Traviata

'(the fact of) my singing the Traviata'

Nominalizations like destruction which do not license accusative case or adverbs involve a relatively low nominal head over a relatively low verbal one; the noun therefore appears with the full range of nominal inflection and modification, and no verbal inflection or modification. HoD allows high nominal over high verbal (Spanish), high nominal over intermediate verbal (English gerund), or low nominal over low verbal (nominalizations like destruction), but not low nominal over high verbal structure. What is ruled out would be, e.g., a structure in which relatively high verbal morphology like tense or the perfect could be dominated by relatively low nominal characteristics, as in *these woolen havings knitted, where the perfect is embedded under a plural and a low adjective. Thus the HoD constraint on extended projections appears to play an important role, suggesting that mixed extended projections should be included in the theory of extended projections.

Besides the putative cases of $\mathrm{D}$ over $\mathrm{C}$ mentioned in note 13, another possible HoD-violating mixed projection is the analysis in Alexiadou et al. (2011) of German verbal infinitives (e.g., das Abholzen des Waldes, 'the deforestation of the forest') as involving $n$ over Asp; $n$ is presumed to be present because of the possibility of adjectival modification and genitive case assignment, while Asp is presumed to be present because of the generic aspect and the possibility of adverbial modification. The nominal category $n$ (parallel to $v$ in the verbal domain) is usually analyzed as part of a lower domain in the HoD than aspect (cf. (39) and (40)), in which case this would violate HoD. However, there are several possibilities for bringing the analysis of German verbal infinitives in line with the HoD. One would be that the locus of genitive case and whatever adjectival modification is possible in these constructions is a higher domain than the one traditionally labeled $n$; another would be that the genericity and adverbial modification observed there are associated with a lower domain than the one commonly labeled Asp. The structure in (39) opens up for a third possible resolution: there, the lowest domain, as represented by the "event" ellipse, includes the category Asp*. In that case, Asp* is actually located in the lowest domain (as well as the overlapping intermediate domain), and so the domination of Asp* by the low $n$ would not in fact constitute a violation of HoD.

The structures in (51) are representative of the kinds of mixed projections which have been discussed.

Mixed extended projections (Borsley \& Kornfilt 2000; Alexiadou et al. 2011)

e.g., English

verbal gerunds e.g., Spanish

infinitives with

$\mathrm{D}$ e.g., English

nominalizations 


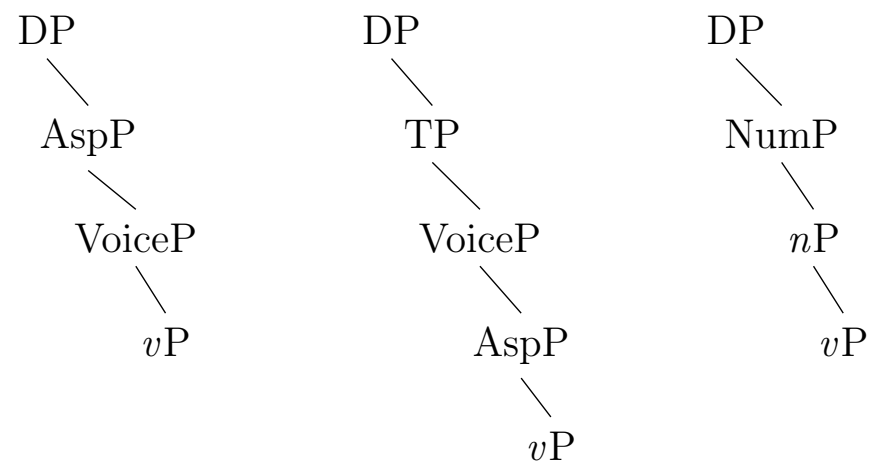

The higher structure determines the external distribution as a DP, and the lower structure determines internal characteristics such as the case on arguments and the form of modifiers, adjectival versus adverbial.

Languages also have low verbalizations, as in caramelize, but fewer clear cases of high verbalization have emerged. In a high verbalization, high verbal functional projections should be added outside high or intermediate nominal ones, for example tense outside a determiner in * Somed late blooms, meaning 'there were some late blooms'. It is unclear why mixed projections usually involve nominal over verbal, and not verbal over nominal, and I will not resolve this highly interesting research question here.

I will analyze Norwegian $\mathrm{P}$ over $\mathrm{C}$ as a mixed projection, and it is HoD-respecting if $\mathrm{P}$ is from as high a domain as $\mathrm{C}$, as Grimshaw suggested. Furthermore, if $\mathrm{P}$ is nominal while $\mathrm{C}$ is verbal, then it is also typical in showing nominal over verbal projections.

\subsection{Mixed extended projections as graphs}

An EF in EPG consisting of a verbal and a nominal category will result in a language allowing a mixed projection. For example, if English gerunds involve D taking Asp as a complement, then $\mathrm{EPG}_{\text {English }}$ contains the $\mathrm{EF}\langle\mathrm{Asp}, \mathrm{D}\rangle$ in addition to the previously mentioned EFs, as represented in (52).

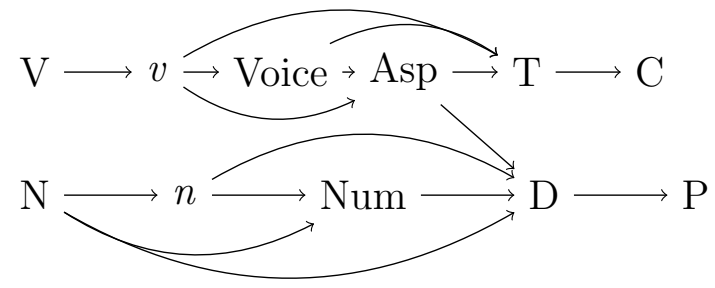

Structurally, such a graph contains paths from $\mathrm{N}$ and $\mathrm{V}$ converging at $\mathrm{D}$, and paths from $\mathrm{V}$ branching at Asp. English also has nominalizations in which a low nominal head dominates a low verbal one.

Here HoDs are implied vaguely by the left-right dimension, but not indicated specifically, because there are unsettled details such as whether there are three domains as in (39) or four as in (40), or some other number. A derivational structure manifesting $n$ over $v$ would constitute part of an extended projection in the terms 
considered here, if $n$ and $v$ are in the same functional domain. An EF from $v$ to $n$ is represented in (53).

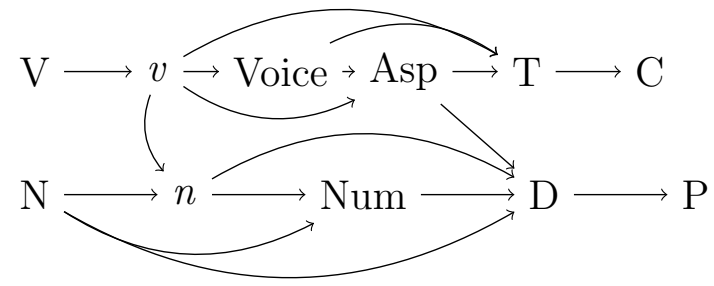

Alexiadou et al. (2011) analyze Spanish nominal infinitives as involving $n$ over Voice. This would be compatible with HoD if Voice and $n$ are in the same domain, for instance the 'Classification' domain of Wiltschko's (2014) (40). Domains can be overtly indicated as in (54), which adds a transition from Voice to $n$. HoD is respected in such a diagram as long as arrows do not point to the left across a domain boundary; the edge from Voice to $n$ angles to the left but within a domain.

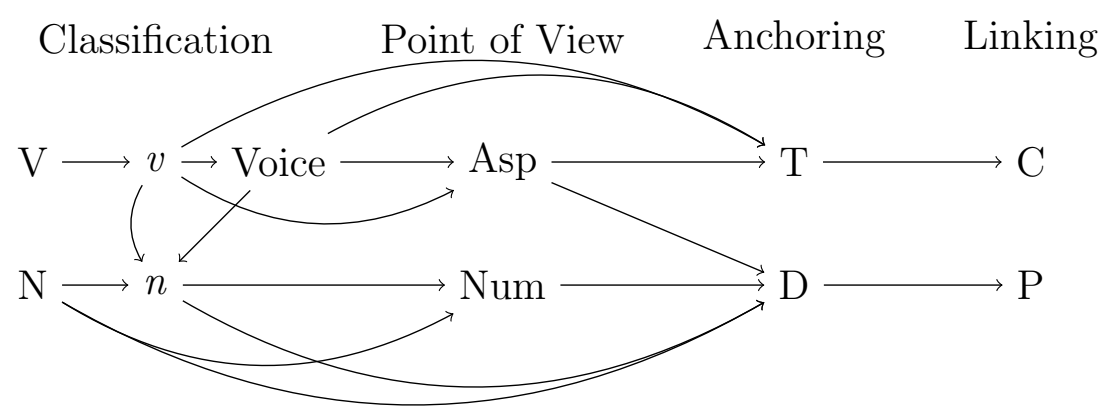

Henceforth I will allow the HoD to remain implicit. Norwegian has nominalizations but lacks gerunds, so has $\langle v, n\rangle$ but lacks $\langle$ Asp, $\mathrm{D}\rangle$. We can now analyze

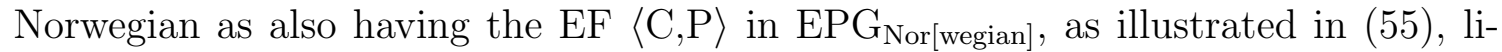
censing the examples in (18-25). English lacks that EF, with the result that the examples in (9-14) are unacceptable.

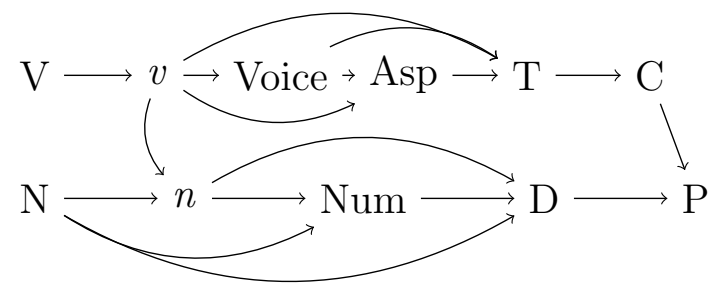

\subsection{EPGs as Finite State Networks}

The EPG can be conceptualized as a finite state network which generates extended projections. A finite state network corresponding to the graph in (46) is depicted in (56). By indicating $\mathrm{V}$ as the only start state in (56), the diagram indicates that all verbal extended projections contain a $\mathrm{V}$ at the bottom (or a categoriless root). If, 
on the other hand, there are verbal extended projections which lack a lexical head and start at $v$, then $v$ would also be designated as a start state.

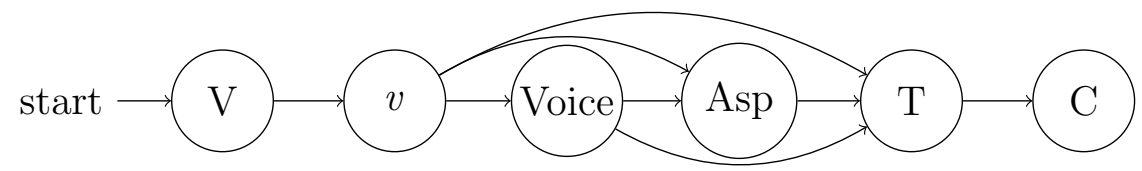

The notation for accepting states, a double border around a state, can be used to indicate which extended projections are 'complete' in the sense that they can be interpreted in embedded positions. For example, (57) would encode the hypothesis that $v \mathrm{P}$ and VoiceP are never embedded without Asp and/or T, but AspP, TP, and $\mathrm{CP}$ are all possible adjuncts or specifiers or lexical complements.

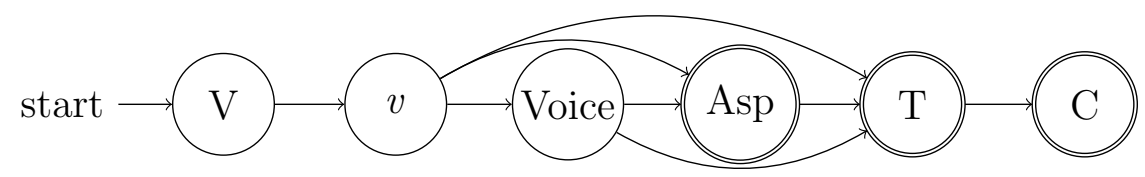

The EPG for English which includes nominalizations and gerunds in (53) is presented as a finite state network in (58).

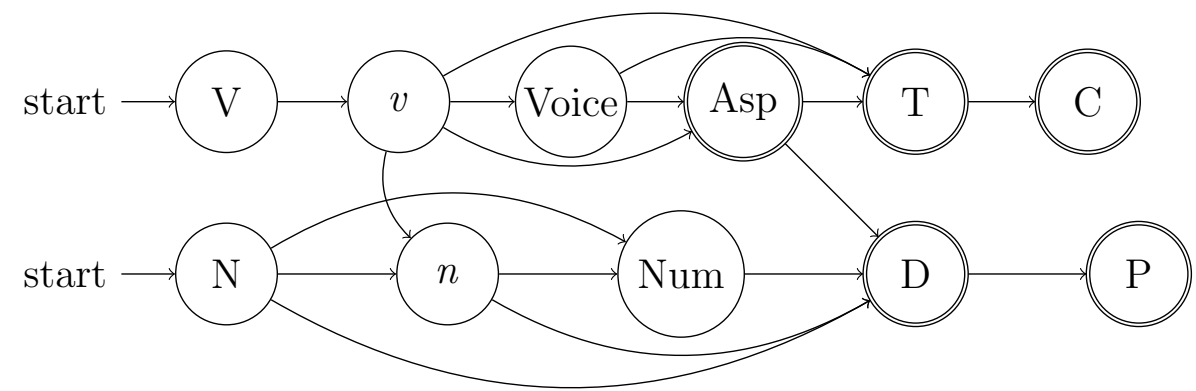

The Norwegian EPG in (55) is represented as a finite state network in (59). The distribution of accepting states is preliminary and is here meant simply to suggest another way in which language-specific HoPs may differ from each other, besides the presence or absence of EFs. In that spirit, I have depicted Norwegian $n$ Ps as accepting states because of the distribution of bare singulars (Borthen 2003), which are arguably $n \mathrm{Ps}$, and I have depicted Norwegian TP as not an accepting state because of matrix V2 and the absence of ECM complements, taking all matrix and embedded clauses to be CP.

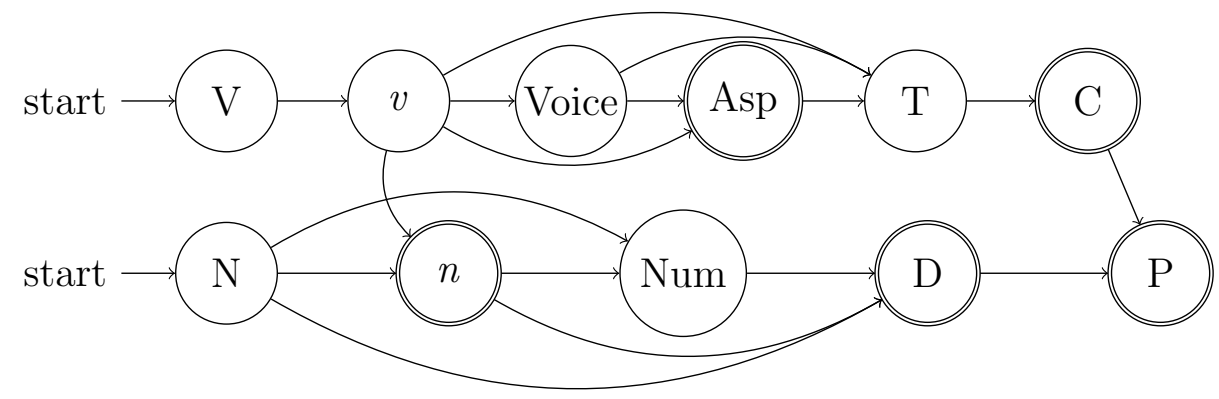




\subsection{Acquisition of EPG}

In acquisition, a Norwegian learner who had not posited the EF $\langle\mathrm{C}, \mathrm{P}\rangle$ would fail to properly parse the examples in (18-25) and in (26-29). The learner would have to add the EF to the grammar in order to successfully parse such examples. To understand that the structures involve $\mathrm{P}$ combining with $\mathrm{CP}$ and projecting $\mathrm{PP}$ is not enough by itself to suggest that $\langle\mathrm{C}, \mathrm{P}\rangle$ is in $\mathrm{EPG}_{\text {Nor }}$. If $\mathrm{P}$ and $\mathrm{C}$ belong to the same domain, as suggested by Grimshaw, then the respective domains of the categories are insufficient to determine what kind of relation they stand in. In principle, a $\mathrm{PP}$ consisting of $\mathrm{P}$ and a $\mathrm{CP}$ could involve a $\mathrm{CP}$ adjunct or specifier. But arguably, CP is not interpreted as a conjunct or the subject of a predication, but is rather interpreted in a way consistent with extended projections - as a 'part' of the denotation of the whole PP, in the terms suggested by Svenonius (2016a). Perhaps the CP is interpreted as the "Ground" of an abstract location; see Svenonius (2007), building on Talmy (1978). In that case, the learner could add the EF $\langle\mathrm{C}, \mathrm{P}\rangle$ to $\mathrm{EPG}_{\mathrm{Nor}}$.

\subsection{The extended projection of $P$}

I have so far represented $\mathrm{P}$ as a single category. However, much work has suggested that P has an extended projection of its own, including van Riemsdijk (1990); Koopman (2000); den Dikken (2010); Svenonius (2010), with some lower projections having more lexical or semilexical characteristics. Norwegian provides ample evidence supporting an extended projection of $\mathrm{P}$, for example there are compound prepositions like the ones in (60) in which a particle is prefixed to the preposition (from Faarlund et al. (1997), a Norwegian reference grammar).

(60) a. Bilen står uten-for porten.

the.car stands out-for the.gate

'The car is outside the gate'

b. Brevet er lagt inn-i konvolutten. the.letter is laid in-in the.envelope

'The letter has been placed inside the envelope'

c. Det var mange båter ut-på sjøen.

it was many boats out-on the.sea

'There were many boats out on the sea.'

These are analyzed by Svenonius \& Taraldsen (2007) as involving a low use of the particle Prt, incorporating to a higher functional $p$, adopting van Riemsdijk's (1990) notation for the functional preposition. If that analysis is correct, then the $\mathrm{EF}\langle$ Prt, $p\rangle$ is part of $\mathrm{EPG}_{\mathrm{Nor}}$.

The functional prepositions here, for, $i$, and $p \stackrel{a}{a}$, have all been shown to appear with CP. But the compound prepositions in (60) do not. So this suggests that it is $p$, not Prt, which dominates $\mathrm{C}$ in $\mathrm{EPG}_{\mathrm{Nor}}$, as indicated in (61). 
(61)

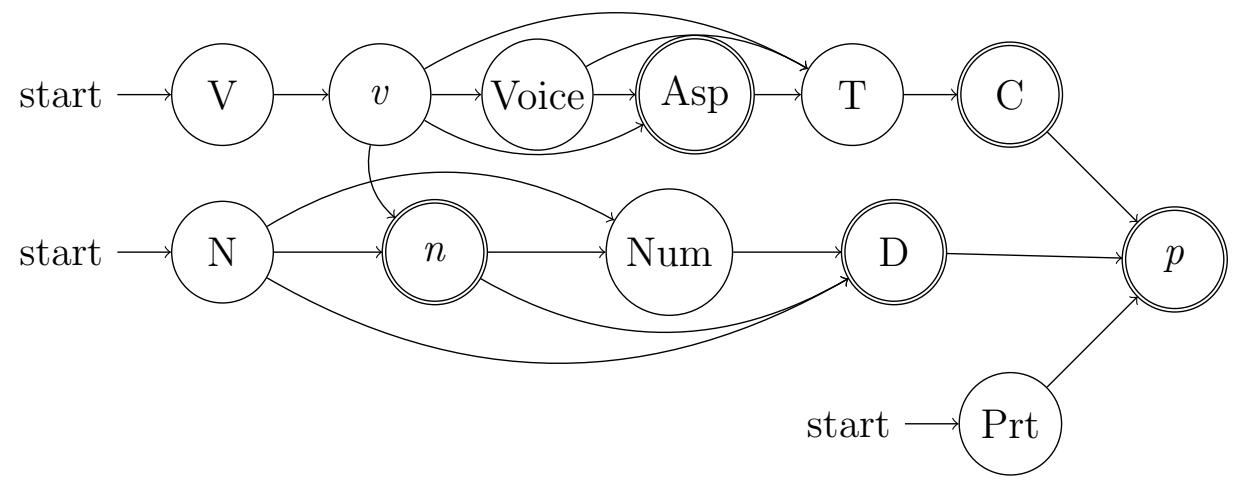

Terzi (2010) and others (see Terzi (2017) for references) have argued that the ground DP in adpositional phrases (e.g., 'the gate' in (60a)) is a kind of possessor in a specifier position of a lexical or semi-lexical head. In that case the ground DP is not a complement of any part of the extended projection of $\mathrm{P}$, so there is no EF $\langle\mathrm{D}, \mathrm{Prt}\rangle$ in an EPG like (61).

Consistent with that perspective, Svenonius \& Taraldsen (2007) suggest that the ground DPs in (60) are specifiers of the particle, not complements (see also note 6); for example the PP in (60b) could be paraphrased 'in the envelope's inside', with the ground as a possessor, as on Terzi's analysis (of Greek). The extended projection of $\mathrm{P}$ in those cases would start at Prt, which is why that node is marked as a start state in (61).

A fuller account of the prepositional HoP would include additional categories such as Path, Place and AxPart, and would include projections for case. If edges connected $\mathrm{D}$ to these categories, they would generally fall under Grimshaw's placement of P. But the inclusion of the node Prt in (61) which is outside any extended projection path starting at $\mathrm{N}$ deviates importantly from the idea that $\mathrm{P}$ in general is the top of the extended projection of $\mathrm{N}$, and contributes to the sense adopted here that EPG is not a collection of nonconnected HoPs, but rather a network, with properties like that of a finite state automaton which generates all and only the extended projections of a language. Clearly, a finite state network is not the complete grammar, as pointed out by Chomsky (1957), but this one subcomponent of the grammar is neatly modeled as one.

\subsection{Revisiting the $H o D$}

The universal HoD appears to play an important role in constraining languagespecific HoPs, in that we do not easily find structures which otherwise show the properties of extended projections but which flout HoD. For instance, the structure of complex words tends strongly to respect HoD, which is part of the same fact if words are understood as subparts of extended projections, as suggested by Brody (2000) and Svenonius (2016b).

However, words regularly include $\mathrm{P}$ elements incorporated to $\mathrm{V}$. Often these are analyzed as lower than $\mathrm{V}$ in an extended projection, as in the analysis of verb-particle constructions in Ramchand \& Svenonius (2002). If $\mathrm{P}$ is higher than $\mathrm{C}$ in HoD, as suggested by the analysis presented above, and $\mathrm{C}$ is clearly higher than $\mathrm{V}$, then how can $\mathrm{P}$ also be lower than $\mathrm{V}$ in an HoP? One possibility is that there are lexical and 
functional Ps, as suggested by van Riemsdijk (1990), so that some P can be lower than $\mathrm{V}$ while other $\mathrm{P}$ are higher. In that case, a fuller EPG would include three parallel strands for $\mathrm{N}, \mathrm{V}$, and $\mathrm{P}$ (and a fourth for A), aligned according to a single HoD from left to right, as assumed in the EPG diagrams so far. Prt in (61) could be drawn further to the left, in order to preserve the left-right representation of the HoD dimension.

Alternatively, however, it is conceivable that one and the same $\mathrm{P}$ has properties which make it natural both for extended projection to $\mathrm{V}$ and from $\mathrm{C}$. Consider, for example, that Path prepositions like til 'to' and fra 'from' are high in the extended projection of P (van Riemsdijk \& Huybregts 2002), and accordingly can be the second element in compound prepositions in Norwegian, as seen in (62), but also appear as verbal prefixes, as seen in (63).

a. Lyden kom ned-fra kjelleren.

the.sound came down-from the.basement

'The sound came from down in the basement'

b. Hendene holdes tett inn-til kroppen.

the.hands hold.PAss close in-to the.body

'The hands must be held tightly against the body'

(63) a. Tyven fra-stjal oss bilen.

the.thief from-stole us the.car

'The thief stole our car from us'

b. De til-lot oss å spille musikk.

they to-let us INF play music

'They let us play music'

The P here can naturally be analyzed as an incorporated part of the complement, as in Baker (1988). The usual assumption would be that a low incorporated $\mathrm{P}$ does not belong to the same extended projection as the $\mathrm{V}$ hosting it; but this seems to be mainly driven by the intuition that the verb is more lexical than the particle and that more functional elements dominate more lexical ones in an extended projection (van Riemsdijk (1998)), an intuition which may be subject to reassessment given the slipperiness of the notion of degrees of lexicality or functionality. As already mentioned, Ramchand \& Svenonius (2002) analyze particles as occupying a low position in the extended projection of the verb. If extended projections form the basis for words, the examples in (63) could be taken as evidence that non-particle $\mathrm{P}$ can be in the extended projection of the verb as well. ${ }^{15}$

Our understanding of $\mathrm{HoD}$ is vague enough that it seems fully possible that a non-transitive relation might replace it. Perhaps rather than being related in a hierarchy (which I believe implies transitivity), domains stand in 'upstream' and

\footnotetext{
${ }^{15}$ This approach implies that in languages with productive noun incorporation, there is an EF from $\mathrm{N}$ to $\mathrm{V}$. I don't see this as problematic.
} 
'downstream' relations to each other, which need not be transitive and might also be gradient. Then the fact that $\mathrm{V}$-related categories are more frequently dominated by elements from the T-domain in extended projections than by elements from the D-domain might reflect the relative strength of the downstream relation, rather than a hierarchy. Overall, this could have the effect that mixed projections are rarer than monocategorial projections, perhaps addressing some of the concerns that led Grimshaw and van Riemsdijk to legislate against mixed projections.

A downstream relation among domains could replace the notion of lexical category, for example the $\mathrm{T}$-domain would be more strongly downstream of the $\mathrm{V}$-domain than is the D-domain, reflecting the cognitive naturalness or functional utility of projecting from one to the other. Frequently manifested projections become grammaticized in the form of EFs added to EPG, perhaps sometimes through the reanalysis of lexical complementation or of adjunction.

\section{Alternatives}

In this section I address and criticize some alternatives to the analysis of Norwegian $\mathrm{P}-\mathrm{CP}$ structures in terms of mixed extended projections.

\subsection{Are Norwegian CPs DPs?}

An alternative attempt to explain the possibility of $\mathrm{CP}$ complements to $\mathrm{P}$ would be to say that Norwegian CPs are DPs, or are noun-phrase-like in some way, while English CPs are not DPs in the same sense. In one way, my proposal actually says this, in that Norwegian CPs are like DPs in their relation to $\mathrm{P}$ (specifically, to $p$ ) in the EPG.

However, there is not much independent evidence for a broader equivalence between Norwegian CP and DP.

Unlike English that, the Norwegian complementizer at does not appear in nominal structures; it is etymologically related to a preposition but is not phonologically identical to any contemporary preposition, determiner, or pronoun in standard Norwegian. ${ }^{16}$

Norwegian finite CPs, like English finite CPs, can appear in non-case thematic positions, for example as the complements of non-case-assigning adjectives, where DPs require a preposition, as seen in (64a), where the preposition is obligatory, versus (64b), where no preposition is needed. This, too, makes CPs distinct from DPs, just as in English.

$$
\begin{aligned}
& \text { a. Hun er glad *(for) resultatet sitt. } \\
& \text { she is happy for the.result POSS.REFL } \\
& \text { 'She is happy about her result' }
\end{aligned}
$$

\footnotetext{
${ }^{16} \mathrm{An}$ at of category $\mathrm{P}$ is preserved in a handful of collocations like bare seg at 'go about it', følges at 'accompany one another'. There is also a particle att 'back', as in fä noe att 'get something back', which bears a word stress, like other particles and unlike the complementizer at.
} 
b. Hun er glad (for) at hun besto eksamenen

she is happy for that she passed the.exam

'She is happy that she passed the exam'

The facts are a bit more complicated than I can do justice to here. There are a few adjectives which take DPs, for example redd 'afraid', and there are many adjectives which require a preposition even with CP complements, like stolt 'proud' ( $a v$ 'of'). But the existence of adjectives like glad 'happy' in (64) shows that CP does not pattern consistently with DP. Interestingly, adjectives like imponert 'impressed' in (65) prescriptively require $\mathrm{P}$ with $\mathrm{CP}$, but are used colloquially with bare $\mathrm{CP}$, as in as seen in (65b), and the same adjectives never appear with bare DP complements, as indicated in (65a). This suggests that the pattern exhibited by glad is expanding.

(65) a. Han er imponert *(over) resultatet sitt.

he is impressed over the.result POSS.REFL

'He is impressed with his result'

b. Han er imponert (over) at han besto eksamenen

he is impressed over that he passed the.exam

'He is impressed that he passed the exam'

Again, the general pattern can be seen with infinitive CP as well.
a. Vi er ferdig (med) å bake.
we is finished with INF bake
'We are finished baking'
b. $\quad V i$ er ferdig * (med) pepperkakehuset.
we is finished with the.gingerbread.house
'We are finished with the gingerbread house'

The fact that DP and CP have different distributions means they cannot be collapsed entirely (see Stowell 1981 for foundational discussion of the issues). On the other hand, as long as it is DP which has the more restricted distribution, the facts are consistent with an optional zero derivation from $\mathrm{C}$ to $\mathrm{D}$. In my terms, this could not be an EF $\langle\mathrm{C}, \mathrm{D}\rangle$, because $\mathrm{C}$ belongs to a higher domain than $\mathrm{D}$, so would have to be an embedding of some kind. DP could not appear in non case positions, and CP by itself could not appear as a complement to P; but CP could zero-derive to DP and appear as a complement to $\mathrm{P}$ in that guise.

However, there are also cases in which it is $\mathrm{CP}$ which has the more restricted distribution, undermining a zero-derivation account. Norwegian finite CPs appear as subjects only when they can be peripheral, just like English CPs, and resist subject position in contexts of inversion (Koster 1978; Lohndal 2014a). This makes them distinct from DPs, in Norwegian as in English. 
(67) a. At gjestene kom tidlig overrasket vertene.

that the.guests came early surprised the.hosts

'That the guests came early surprised the hosts'

b. *Overrasket at gjestene kom tidlig vertene? surprised that the.guests came early the.hosts

*'Did that the guests come early surprise the hosts?'

If $\mathrm{CP}$ could zero-derive to become DP, there would be no explanation for the badness of $\mathrm{CP}$ in the specifier of $\mathrm{TP}$.

\subsection{Is there a null $D$ and/or $N$ in the P-CP construction?}

An intriguing possibility is that there could be nominal structure between $\mathrm{P}$ and $\mathrm{CP}$ in examples like those in (18-25) and (26-29). This possibility is initially made plausible by the fact that Norwegian allows both finite and infinitive CPs with pronouns, as in (68-69) (compare (17) and (27a), which are string-identical except for the presence of the pronoun). I gloss the pronoun det 'it' here but it could alternatively be glossed 'that'; Norwegian det is not a perfect equivalent for either of the English counterparts. Unambiguously demonstrative pronouns are also possible, including the bipartite dialectal det her "the here" ('this') and det der "the there" ('that'), with the added implication that the proposition has been previously mentioned or at least implied in the discourse.

(68) Man må tenke på det at sneglene trenger gjemmesteder one must think on it that the.snails need hide.places

'One must consider that snails need hiding places'

$$
\begin{aligned}
& \text { Jeg er ikke glad } i \text { det } \stackrel{\circ}{a} \text { fryse } \\
& \text { I am not happy in it INF freeze }
\end{aligned}
$$

'I don't like being cold'

If $\mathrm{D}$ is lower than $\mathrm{C}$ in HoD, as suggested by (40), then these examples could not involve single extended projections but must involve $\mathrm{CP}$ adjoined to $\mathrm{D}$ or to a lower head in the nominal extended projection, or perhaps as a lexical complement to a null $\mathrm{N}$ below $\mathrm{D}$. This in turn raises the possibility that (18-25) and (26-29) involve null nominal structure but are otherwise like (68) and (69).

However, there are good reasons to think that the structures of the two are different. For one thing, the distribution of the putative null $\mathrm{D}$ would have to be different from the overt one; for example the CP subject in (67) cannot appear in $\mathrm{TP}$ under a verb in $\mathrm{C}$, as already noted, but a subject consisting of a pronoun plus a CP can, as seen in (70) (cf. Faarlund et al. 1997; Lohndal 2014b). 
'Did it surprise the hosts that the guests came early?'

A further apparent difference between CPs with and without det is that extraposition is impossible for CP subjects without det, but possible for $\mathrm{CP}$ subjects with det, as seen in (71).

(71) a. Overrasket det vertene at gjestene kom tidlig? surprised it the.hosts that the.guests came early

'Did it surprise the hosts that the guests came early?'

b. *Overrasket vertene at gjestene kom tidlig? surprised the.hosts that the.guests came early

(intended: 'Did it surprise the hosts that the guests came early?')

Though on an alternative analysis, extraposition of $\mathrm{CP}$ without a pronoun requires that an overt expletive det be left behind, while extraposition of the CP with a pronoun forbids an additional pronoun to be left behind, with the consequence that extraposition in the two cases yields identical strings.

Another striking difference between the two structures, noted by Kristine Bentzen (personal communication), is that extraction is impossible from a CP which accompanies a pronoun, while it is unproblematic from an otherwise similar CP without one, if it appears in a suitable position, for example a complement to a $\mathrm{P}$ in complement position.

Hva husket hun på at sneglene trenger?

what remembered she on that the.snails need

'What did she remember that snails need?'

*Hva husket hun på det at sneglene trenger?

what remembered she on it that the.snails need

('What did she remember that snails need?')

This is straightforwardly explained if $\mathrm{CP}$ with det is an adjunct to the pronoun, as adjunct clauses are standardly islands, while $\mathrm{CP}$ without det is a complement to $\mathrm{P}$, as proposed in the analysis here.

\subsection{Summary}

In this short section, I have attempted to respond to what I anticipate as the most likely alternatives to my account in terms of mixed extended projections. 


\section{Conclusion}

In this paper, I have examined the pattern in Norwegian whereby all common functional prepositions appear freely with finite and infinitive CP clausal complements, in sharp contrast to English. I have argued that this constitutes a mixed projection of the type identified by Abney (1987) and Borsley \& Kornfilt (2000), in which a nominal functional head takes a verbal projection as its complement in an extended projection.

This represents an important departure from the conception of extended projection in Grimshaw (2005), which relies on a universal and rich HoP, and on categorial integrity (van Riemsdijk 1990). I have introduced more flexibility, allowing crosslinguistic variation and reducing the explanatory burden on UG but increasing the burden on the theory of acquisition. I have made some suggestions concerning how EFs might be acquired, drawing on the hypothesis that there is a strong connection between structure and interpretation (more specifically along the lines sketched in Svenonius 2016a). This allows learners to infer certain aspects of structure (such as the presence of an extended projection relation and hence an EF) on the basis of interpretation.

An important consequence of mixed projections is that categorial integrity is compromised. If we can no longer ensure that $\mathrm{P}$ appears in the extended projection of $\mathrm{N}$, as opposed to $\mathrm{V}$, is there a clear sense in which $\mathrm{P}$ even belongs to the extended projection of N? Actually, many prepositions show verbal characteristics, especially when they appear as parts of complex predicates. Some previous work has analyzed prepositional particles as low parts of the extended projection of $\mathrm{V}$. If these same particles are high in the extended projection of $\mathrm{P}$, as suggested by the fact that they are directional (and directional $\mathrm{P}$ normally dominates locative $\mathrm{P}$, van Riemsdijk \& Huybregts 2002; Svenonius 2008), then it is possible that the HoD is not transitive; that is, $\mathrm{V}$ could be higher than $\mathrm{P}$, while $\mathrm{P}$ is higher than $\mathrm{D}$, and $\mathrm{D}$ is higher than $\mathrm{V}$.

I have identified the EPG as a property of categories, not of individual lexical entries of heads. This is important to distinguish English, in which individual senses of individual prepositions can take CPs as lexical complements, from Norwegian, in which $\mathrm{P}$ as a category forms extended projections with $\mathrm{CP}$. This is a departure from the narrowest interpretation of Borer's (1984) conjecture, in which all crosslinguistic variation lies in the properties of heads. Here I must distinguish properties of heads from properties of categories.

\section{Acknowledgments}

Thanks to the participants at the workshop on morphosyntactic variation in adpositions at the University of Cambridge in May 2017 for inspiration, to the editors of this volume for their encouragement, and to two anonymous reviewers for useful feedback. 


\section{References}

Abney, Steven. 1987. The English noun phrase in its sentential aspect. Cambridge, Ma.: MIT dissertation.

Adger, David. 2013. A syntax of substance. Cambridge, Ma.: MIT Press.

Alexiadou, Artemis. 2001. Functional structure in nominals: Nominalization and ergativity. Amsterdam: John Benjamins.

Alexiadou, Artemis. 2011. The aspectual properties of nominalization structures. In Alexandra Galani, Glyn Hicks \& George Tsoulas (eds.), Morphology and its interfaces, 47-72. Amsterdam: John Benjamins.

Alexiadou, Artemis, Gianina Iordăchioaia \& Florian Schäfer. 2011. Scaling the variation in Romance and Germanic nominalizations. In Antonia Petronella Sleeman \& Harry Perridon (eds.), The noun phrase in Romance and Germanic: Structure, variation, and change, 25-40. Amsterdam: John Benjamins.

Baker, Mark C. 1988. Incorporation: A theory of grammatical function changing. Chicago: University of Chicago Press.

Baltin, Mark R. 1989. Heads and projections. In Mark R. Baltin \& Anthony S. Kroch (eds.), Alternative conceptions of phrase structure, 1-16. Chicago: University of Chicago Press.

Boeckx, Cedric. 2010. Why edges are needed. In Anna Maria Di Sciullo \& Virginia Hill (eds.), Edges, heads, and projections: Interface properties, 11-22. Amsterdam: JohnBenjamins.

Borer, Hagit. 1984. Parametric syntax. Dordrecht: Foris.

Borer, Hagit. 2005. The normal course of events (structuring sense, vol. ii). Oxford: Oxford University Press.

Borsley, Robert D \& Jaklin Kornfilt. 2000. Mixed extended projections. In Robert D. Borsley (ed.), The nature and function of syntactic categories, 101-131. San Diego, Ca.: Academic Press.

Borthen, Kaia. 2003. Norwegian bare singulars: NTNU, Trondheim dissertation.

Bresnan, Joan. 1972. Theory of complementation in English syntax. Cambridge, Ma.: MIT dissertation.

Brody, Michael. 2000. Mirror Theory: Syntactic representation in Perfect Syntax. Linguistic Inquiry 31(1). 29-56.

Chomsky, Noam. 1957. Syntactic structures. 's-Gravenhage: Mouton.

Chomsky, Noam. 1995. The minimalist program. Cambridge, Ma.: MIT Press. 
Chomsky, Noam. 2007. Approaching UG from below. In Uli Sauerland \& HansMartin Gärtner (eds.), Interfaces + recursion = language? chomsky's minimalism and the view from syntax-semantics, 1-18. Berlin: Mouton de Gruyter.

Chomsky, Noam. 2008. On phases. In Robert Freidin, Carlos P. Otero \& Maria Luisa Zubizarreta (eds.), Foundational issues in linguistic theory: Essays in honor of Jean-Roger Vergnaud, 133-166. Cambridge, Ma.: MIT Press.

Chomsky, Noam. 2013. Problems of projection. Lingua 130. 33-49.

Cinque, Guglielmo. 1999. Adverbs and functional heads: A cross-linguistic perspective. New York: Oxford University Press.

den Dikken, Marcel. 2010. On the functional structure of locative and directional PPs. In Guglielmo Cinque \& Luigi Rizzi (eds.), Mapping spatial PPs: Cartography of syntactic structures, vol. 6, 74-126. Oxford: Oxford University Press.

Elbourne, Paul. 2008. The argument from binding. Philosophical Perspectives 22(1). 89-110.

Emonds, Joseph. 1985. A unified theory of syntactic categories (Studies in Generative Grammar 19). Dordrecht: Foris.

Faarlund, Jan Terje, Svein Lie \& Kjell Ivar Vannebo. 1997. Norsk referansegrammatikk. Oslo: Universitetsforlaget.

Fillmore, Charles J. 1968. The case for case. In Emmon Bach \& Robert T. Harms (eds.), Universals in linguistic theory, 1-88. New York: Holt, Rinehart, and Winston.

Gawron, Jean Mark. 1986. Situations and prepositions. Linguistics and Philosophy $9(3) .327-382$.

Grimshaw, Jane. 1991. Extended projections. Ms. Brandeis University.

Grimshaw, Jane. 2005. Extended projection. In Jane Grimshaw (ed.), Words and structure, 1-73. Stanford, Ca.: CSLI. Revised version of $1991 \mathrm{~ms}$.

Hale, Ken \& Samuel Jay Keyser. 2002. Prolegomenon to a theory of argument structure (Linguistic Inquiry Monographs 39). Cambridge, Ma.: MIT Press.

Haumann, Dagmar. 2011. The syntax of subordination. Berlin: Walter de Gruyter.

Jackendoff, Ray. 1973. The base rules for prepositional phrases. In Stephen Anderson \& Paul Kiparsky (eds.), A festschrift for morris halle, 345-356. New York: Holt.

Jackendoff, Ray. 1977. $\bar{X}$ syntax: A study of phrase structure (Linguistic Inquiry Monograph 2). Cambridge, Ma.: MIT Press.

Koopman, Hilda. 2000. Prepositions, postpositions, circumpositions, and particles. In Hilda Koopman (ed.), The syntax of specifiers and heads, 204-260. London: Routledge. 
Kornfilt, Jaklin \& John Whitman. 2011. Afterword: Nominalizations in syntactic theory. Lingua 121(7). 1297-1313.

Koster, Jan. 1978. Why subject sentences don't exist. In Samuel Jay Keyser (ed.), Recent transformational studies in European languages, 53-64. Cambridge, Ma.: MIT Press.

Lohndal, Terje. 2014a. Sentential subjects in English and Norwegian. Syntaxe et Sémantique 15(1). 81-113.

Lohndal, Terje. 2014b. Sentential subjects: Topics or real subjects? In Robert E. Santana-LaBarge (ed.), Proceedings of the 31st west coast conference on formal linguistics, 315-324. Somerville, Ma.

Pesetsky, David. 1982. Paths and categories. Cambridge, Ma.: MIT dissertation.

Pietroski, Paul M. 2005. Events and semantic architecture. Oxford: Oxford University Press.

Ramchand, Gillian. 2008. Verb meaning and the lexicon. Cambridge: Cambridge University Press.

Ramchand, Gillian \& Peter Svenonius. 2002. The lexical syntax and lexical semantics of the verb-particle construction. In Line Mikkelsen \& Christopher Potts (eds.), Proceedings of WCCFL 21, 387-400. Somerville, Ma.: Cascadilla Press.

Ramchand, Gillian \& Peter Svenonius. 2014. Deriving the functional hierarchy. Language Sciences 46(B). 152-174.

Rauh, Gisa. 1993. On the grammar of lexical and non-lexical prepositions in English. In Cornelia Zelinsky-Wibbelt (ed.), The semantics of prepositions: From mental processing to natural language processing, 99-150. Berlin: Mouton de Gruyter.

van Riemsdijk, Henk. 1990. Functional prepositions. In H. Pinkster \& I. Genée (eds.), Unity in diversity, 229-241. Dordrecht: Foris.

van Riemsdijk, Henk. 1998. Categorial feature magnetism: The endocentricity and distribution of projections. Journal of Comparative Germanic Linguistics 2. 1-48.

van Riemsdijk, Henk \& Riny Huybregts. 2002. Location and locality. In Marc van Oostendorp \& Elena Anagnostopoulou (eds.), Progress in grammar: Articles at the 20th anniversary of the comparison of grammatical models group in Tilburg, 1-23. Amsterdam: Meertens Instituut. www.meertens.knaw.nl/books/progressingrammar/.

Rijkhoff, J. 2002. The noun phrase. Oxford: Oxford University Press.

Rizzi, Luigi. 1997. The fine structure of the left periphery. In Liliane Haegeman (ed.), Elements of grammar: Handbook in generative syntax, 281-337. Dordrecht: Kluwer. 
Sheehan, Michelle \& Wolfram Hinzen. 2011. Moving towards the edge. Linguistic Analysis 37(3-4). 405-458.

Stowell, Tim. 1981. Origins of phrase structure. Cambridge, Ma.: MIT dissertation.

Stowell, Tim. 1996. The phrase structure of tense. In Johan Rooryck \& Lauri Zaring (eds.), Phrase structure and the lexicon, 277-291. Dordrecht: Kluwer.

Svenonius, Peter. 1996. Review of den Dikken 1995, Particles. Language 74. 816-820.

Svenonius, Peter. 2003. Limits on P: filling in holes vs. falling in holes. Nordlyd, Tromsø Working Papers on Language and Linguistics. Proceedings of the 19th Scandinavian Conference of Linguistics 31(2). 431-445.

Svenonius, Peter. 2007. Adpositions, particles, and the arguments they introduce. In Eric Reuland, Tanmoy Bhattacharya \& Giorgos Spathas (eds.), Argument structure, 71-110. Amsterdam: John Benjamins.

Svenonius, Peter. 2008. Projections of P. In Anna Asbury, Jakub Dotlačil, Berit Gehrke \& Rick Nouwen (eds.), Syntax and semantics of spatial p, 63-84. Amsterdam: John Benjamins.

Svenonius, Peter. 2010. Spatial prepositions in English. In Guglielmo Cinque \& Luigi Rizzi (eds.), Mapping spatial PPs: Cartography of syntactic structures, vol. 6, 127-160. Oxford: Oxford University Press. Prepublication draft available at http://ling.auf.net/lingBuzz/000001.

Svenonius, Peter. 2016a. Complex predicates as complementation structures. In Léa Nash \& Pollet Samvelian (eds.), Approaches to complex predicates, 212-247. Leiden: Koninklijke Brill.

Svenonius, Peter. 2016b. Spans and words. In Heidi Harley \& Daniel Siddiqi (eds.), Morphological metatheory, 199-220. Amsterdam: John Benjamins.

Svenonius, Peter \& Knut Tarald Taraldsen. 2007. The construct state in Norwegian prepositional phrases. Ms. CASTL, University of Troms $\varnothing$.

Talmy, Leonard. 1978. Figure and ground in complex sentences. In Joseph H. Greenberg (ed.), Universals of human language, vol. 4, 625-649. Stanford, Ca.: Stanford University Press.

Terzi, Arhonto. 2010. Locative prepositions and Place. In Guglielmo Cinque \& Luigi Rizzi (eds.), Mapping spatial PPs: Cartography of syntactic structures, vol. 6, 196-224. Oxford: Oxford University Press.

Terzi, Arhonto. 2017. Complex spatial expressions. In Martin Everaert \& Henk van Riemsdijk (eds.), The wiley blackwell companion to syntax, 1-25. Wiley 2nd edn.

Wiltschko, Martina. 2014. The universal structure of categories: Towards a formal typology. Cambridge: Cambridge University Press. 